\title{
Studies on the effect of brown rice and maize flour on the quality of bread
}

\author{
M. Z. Islam ${ }^{1}$ and M. Shams-Ud-Din ${ }^{2}$ and M. A. Haque ${ }^{3}$ \\ ${ }^{1}$ Department of Food Engineering and Tea Technology, Shahjalal University of Science and Technology, Sylhet- \\ 3114, ${ }^{2}$ Department of Food Technology and Rural Industries, Bangladesh Agricultural University, Mymensingh and \\ ${ }^{3}$ Department of Food Technology and Nutritional Science, Mawlana Bhashani Science and Technology University \\ Santosh, Tangail-1902, Email: zohurulislam.engg@gmail.com
}

\begin{abstract}
Breads were prepared with various combinations of maize, brown rice and wheat flours in the basic formulation of bread. The baking properties and chemical composition of bread were evaluated and analysed, respectively. The bread volume decreased, where as bread weight and moisture content increased with the increasing level of maize and brown rice flour. The crumb and crust colour of breads were improved with addition of $8 \%$ maize and $8 \%$ brown rice flour in bread formulation. The protein content and other nutrients of breads were increased by addition of maize and brown rice flours. The effects of various levels of yeast, sugar, fat, improver and salt on the quality of breads prepared with maize and brown rice flour were evaluated. Bread quality in respects of bread volume and crumb texture were improved by using $2.5 \%$ yeast, $5 \%$ sugar, $5 \%$ fat and $0.6 \%$ improver. The analysis of bread containing added $8 \%$ maize and $8 \%$ brown rice flours showed protein $9.76 \%$, fat $4.10 \%$, ash $2.10 \%$, crude fibre $5.16 \%$, sugar $2.26 \%$ and total carbohydrates $46.91 \%$. Bread having $8 \%$ maize and $8 \%$ brown rice flour had most acceptable flavour, texture, colour and overall acceptability when compared with other bread with maize and brown rice flour.
\end{abstract}

Keywords: Bread, Brown rice flour, Maize flour, Wheat flour

\section{Introduction}

Brown rice is the entire grain with only the inedible outer husk removed. The nutritious, high-fiber bran coating gives it a light tan color, nutlike flavor and chewy texture. Whole-grain brown rice flours add a different flavor and chewy texture to baked products. Such flours from raw, untreated rice grains have limited shelf-life stability, due chiefly to lipase activity (initiated in bran layers during flour milling), which causes enzymatic hydrolysis of lipid components to free fatty acids. Several methods exist for stabilizing rice bran separated during the raw milled rice (Sayre et al. 1982). The rice bran contains 12-16\% protein which has high nutritional value. The addition of rice bran improves the lysine content of baked product and also contributes a bland pleasant flavor (Lynn, 1969).

Maize is a high energy food having highly digestible carbohydrate, high protein content composed of amino acids essential for human nutrition, cholesterol free oil and good quantity of trace minerals (Martin and Leonard, 1967). Maize is a fairly rich in vitamins-B and the yellow kernel is also good source of the pro-vitamin-A, beta-carotene, which can prevent human blindness. It contains $11.2 \%$ protein, $66.2 \%$ carbohydrates, $3.6 \%$ fat, $1.5 \%$ minerals and $2.7 \%$ fiber (Gopalan et al. 1981). In our country maize is confined in roasted cob, a poultry feed, fodder, starch and snacks. Other forms of food using maize flour alone or mixed with flours from other cereals and pulses include bread, chapati, parota, pulse puri, soup, mixed food, bhutta polao etc. thus the development of the technology for effective utilization of nonwheat flour like brown rice flour, maize flour may be a part of the subject of research in the field of cereal processing technology in the country.

Bread is the most widely used breakfast items in urban and sub-urban areas in Bangladesh. Around the world bread is the principal food and provides more nutrients than any other single food source. In most European countries it is the source of half of the total carbohydrates requirements, one third of the protein requirements, and over $50 \%$ of the B-vitamins and $75 \%$ of vitamin-E requirements (Pomeranz and Shellenberger, 1971). As a result of changing food habits, increasing population and urbanization the consumption of leavened wheat bread has risen dramatically in many developed countries including Bangladesh. On the other hand for climatic reason many developing countries can not grow wheat suitable for bread making. Thus partial substitutions of wheat flour with flour from indigenous crops or the production of alternative wheat less bread may be the subject of research. 
Taking the above points in considerations the present study was undertaken with the following objectives:

i. to develop dietary fiber-enriched baked product such as bread by incorporation of brown rice, maize and wheat flour in the formulations;

ii. to study the effect of various levels of brown rice and maize flour on loaf quality, composition and sensory properties of prepared bread.

\section{Materials and Methods}

The investigation was conducted in the laboratory of the Department of Food Technology and Rural Industries, Bangladesh Agricultural University, Mymensingh, Bangladesh. The maize, raw paddy (pajam) and commercial wheat flours were collected from local market. Brown rice flour was processed from pajam variety by removing the husk. Maize flour was processed from the straw yellow varieties of maize, free from immature, field damage and black maize. The samples were grounded to powder in a flour mill. The initial samples of brown rice and maize flour were analyzed for moisture content, ash, protein and fat as per the methods of AOAC (2004). All the determinations were done in triplicate and results were expressed as the average value in Table 1 . The breads were prepared with various levels of brown rice and maize flour in the formulation. The replacements of wheat flour in the formulation were made with 0 , $5,8,11$ and $14 \%$ of brown rice and maize flour respectively.

\section{Table 1. Formulation of Bread}

\begin{tabular}{|l|c|c|c|c|c|}
\hline \multirow{2}{*}{ Ingredients } & \multicolumn{5}{|c|}{ Bread Formulation } \\
\cline { 2 - 6 } & $\mathrm{A}$ & $\mathrm{B}$ & $\mathrm{C}$ & $\mathrm{D}$ & $\mathrm{E}$ \\
\hline Wheat flour (g) & 100 & 90 & 84 & 78 & 72 \\
\hline Maize flour (g) & 0.0 & 5 & 8 & 11 & 14 \\
\hline Brown rice flour (g) & 0.0 & 5 & 8 & 11 & 14 \\
\hline${ }^{1}$ Dry yeast (g) & 2.5 & 2.5 & 2.5 & 2.5 & 2.5 \\
\hline${ }^{2}$ Salt (g) & 2.5 & 2.5 & 2.5 & 2.5 & 2.5 \\
\hline${ }^{3}$ Sugar $(\mathrm{g})$ & 2 & 2 & 2 & 2 & 2 \\
\hline${ }^{4}$ Fat (g) & 2 & 2 & 2 & 2 & 2 \\
\hline Water (ml) & 65 & 65 & 65 & 65 & 65 \\
\hline${ }^{*}$ Bread improver (g) & 1.2 & 1.2 & 1.2 & 1.2 & 1.2 \\
\hline
\end{tabular}

*Bread improver consists of a mixture of potassium bromate $0.30 \mathrm{~g}$, ascorbic acid $0.50 \mathrm{~g}$, calcium sulphate $7.5 \mathrm{~g}$, ammonium chloride $5.0 \mathrm{~g}$ and malt flour $36.07 \mathrm{~g}$.

${ }^{1}$ Dry yeast were added at the level of 0.25 to $3 \%$ on the flour weight basis.

${ }^{2}$ Salt were added at the level of 0.5 to $3 \%$ on the flour weight basis.

${ }^{3}$ Sugar were added at the level of 1 to $6 \%$ on the flour weight basis.

${ }^{4}$ Fat were added at the level of 1 to $6 \%$ on the flour weight basis.

*Bread improver were added at the level of 0.2 to $0.70 \%$ on the flour weight basis.

Breads were prepared as per the procedures described by kent (1984). Bread volume was initially used as an important parameter of bread quality. The bread volume was determined by seed displacement method (ott, 1987). The results were expressed in $\mathrm{cc}(\mathrm{ml})$ and the values were average of three replications. Loaf weight, moisture content, colour, crust and crumb quality were also determined with the following standard methods described by Kent (1984) and ott (1987).

\section{Results and Discussion}

Composition of brown rice and maize flour: The results of the proximate composition analysis of brown rice and maize flour are presented in Table 2. The Table showed that brown rice flour contained moisture $10.75 \%$, protein $8.24 \%$, fat $2.65 \%$, ash $1.5 \%$, crude fibre $2.25 \%$ and total carbohydrate $76.86 \%$. The findings of this analysis are in agreement with that of Grist (1965) who reported $9.67-9.54 \%$ protein, 2.0-2.54\% fat, $1.19-1.9 \%$ ash, $0.16-0.4 \%$ crude fibre and $79-91.4 \%$ total carbohydrate. Julialo (1972) reported that $7.1-15.4 \%$ proetin, $0.6-4.0 \%$ fat, $0.2-2.6 \%$ fibre, $0.5-2.1 \%$ ash. McCall et al. (1951) observed the range of moisture of brown rice was $9.1-12.6 \%$. 
The prepared maize flour was analyzed for its composition. The results are presented in Table 2 . The analysis showed that the maize flour contained moisture $8.98 \%$, protein $9.0 \%$, fat $3.50 \%$, ash $1.48 \%$ and total carbohydrate $78.04 \%$. The moisture, protein, fat and ash content were more or less similar and carbohydrate contents higher than those reported by Kent (1990). He reported that the maize flour contains $12.6 \%$ moisture $9.4 \%$ protein $4.1 \%$ fat, $1.4 \%$ ash, and crude fibre $2.0 \%$ and $72.1 \%$ carbohydrates. All results are also shown in dry basis (db). The differences observed in these compositions may be due to the following reasons are varietal differences, agro-ecological condition, extent of drying, fertilizer use and methods of analysis etc.

Table 2. Composition of brown rice and maize flour

\begin{tabular}{|l|c|c|}
\hline Components & Brown rice flour & Maize flour \\
\hline Moisture (\%) & $10.75(12.04 \mathrm{db})$ & $8.98(9.86 \mathrm{db})$ \\
\hline Protein (\%) & $8.24(8.98 \mathrm{db})$ & $9.00(9.88 \mathrm{db})$ \\
\hline Fat (\%) & $2.65(2.97 \mathrm{db})$ & $2.50(2.75 \mathrm{db})$ \\
\hline Ash (\%) & $1.50(1.68 \mathrm{db})$ & $1.48(1.63 \mathrm{db})$ \\
\hline Crude fibre (\%) & $2.10(2.35 \mathrm{db})$ & $2.25(2.47 \mathrm{db})$ \\
\hline $\begin{array}{l}\text { Total carbohydrates (\%by } \\
\text { difference) (\%) }\end{array}$ & $76.86(86.12 \mathrm{db})$ & $78.04(85.74 \mathrm{db})$ \\
\hline
\end{tabular}

The parenthesis values $(\mathrm{db})$ indicate dry basis

\section{The effect of maize and brown rice flour on bread properties}

Physical properties of breads incorporating brown rice and maize flour: The effects of maize and brown rice flour on the breads are presented in Table 3. It can be seen from Table 3. that the control bread gave higher volume (512cc) than those other breads prepared with 5, 8, 11 and 14 levels of brown rice and maize flour. It was also observed that the bread volume progressively decreases with the increasing of brown rice and maize flour in the formulation. Since brown rice and maize flour does not contain gluten, its substitution in wheat flour reduced the gluten content in the dough. This might be due to decrease in volume of bread containing brown rice and maize flour. The breads with different levels of maize and brown rice flour had higher moisture contents (36.25-40.10 \%) than that of the control bread. The moisture content of the bread samples gradually decreases with reducing the level of maize and brown rice flour in dough. This might be due to the fact that higher moisture content in composite flour bread contained higher amount of fibre (cellulose, hemicelluloses, or pentosans, lignin and other dietary fiber components) which are contributed by maize and brown rice flour in the dough. These might hold the water which may contribute to the higher moisture content of the maize and brown rice flour containing bread. Similarly the weights of the bread prepared with different level of maize and brown rice flours in the formulation observed that all the bread samples $(230-246 \mathrm{gm})$ had higher weights than that of control bread (220 g).

Table 3. Effect of maize and brown rice flour on volume, weight, specific volume and moisture content of bread

\begin{tabular}{|c|c|c|c|c|c|}
\hline Bread with & $\begin{array}{l}\text { Volume } \\
\text { (cc) }\end{array}$ & $\begin{array}{l}\text { Weight } \\
(\mathrm{g})\end{array}$ & $\begin{array}{c}\text { Specific volume } \\
(\mathrm{cc} / \mathrm{g})\end{array}$ & Colour & $\begin{array}{c}\text { Moisture content } \\
(\%)\end{array}$ \\
\hline $\begin{array}{l}\text { Maize flour }=0 \\
\text { Brown rice flour }=0\end{array}$ & 512 & 220 & 2.327 & $\begin{array}{l}\text { Light } \\
\text { brown }\end{array}$ & 35.16 \\
\hline $\begin{array}{l}\text { Maize flour }=5 \\
\text { Brown rice flour }=5\end{array}$ & 498 & 230 & 2.165 & $\begin{array}{c}\text { Light } \\
\text { brown }\end{array}$ & 36.25 \\
\hline $\begin{array}{l}\text { Maize flour }=8 \\
\text { Brown rice flour }=8\end{array}$ & 490 & 237 & 2.067 & $\begin{array}{l}\text { Light } \\
\text { brown }\end{array}$ & 37.17 \\
\hline $\begin{array}{l}\text { Maize flour=11 } \\
\text { Brown rice flour }=11\end{array}$ & 475 & 240 & 1.979 & $\begin{array}{c}\text { Red } \\
\text { brown }\end{array}$ & 39.15 \\
\hline $\begin{array}{l}\text { Maize flour }=14 \\
\text { Brown rice flour }=14\end{array}$ & 470 & 246 & 1.91 & $\begin{array}{c}\text { Red } \\
\text { brown }\end{array}$ & 39.71 \\
\hline
\end{tabular}


Physical Properties of bread: General appearance, crust and crumb characteristics of bread containing brown rice and maize flour are presented in Table 4. It is observed that control bread had better appearance compared with 5, 8, 11 and 14\% brown rice and maize flour containing bread. The crust colour of the bread containing 5\% brown rice and 5\% maize flour and the bread containing $8 \%$ brown rice and $8 \%$ maize flour were deeper than those of the control bread and other bread samples. The bread containing $11 \%$ maize and $11 \%$ brown rice flour and bread containing $14 \%$ maize and $14 \%$ brown rice flour had harder crust compared to both the control and the bread containing 8\% brown rice and $8 \%$ maize flour. The overall crust characteristics of the bread containing $8 \%$ brown rice and $8 \%$ maize flour seemed to be better than other samples. In general, the differences in crust colour between different bread samples become larger as the substitution levels of maize and brown rice flour increased in dough. Crumb colour of the breads containing different level of maize and brown rice flour is presented in Table 4. Colour evaluation was made with interior slices. As shown in Table 4. the crumb colour of bread containing $14 \%$ maize and $14 \%$ brown rice flour was generally yellowish than the control sample. As a whole, the bread containing 5\% maize and 5\% brown rice flour and bread containing $8 \%$ maize and $8 \%$ brown rice flour had better crumb colour than those obtained from different levels of maize and brown rice flour. This might be due to the yellow colour of the maize flour. The decrease in the levels of maize and brown rice flour substitution changed the crumb colour of the samples from yellowish to white yellow. A good colour regardless of kinds of bread is always desirable.

A significant differences in texture was observed between bread without maize and brown rice flour and bread having $14 \%$ maize and $14 \%$ brown rice flour and this differences increased with increasing the levels of maize and brown rice flour.

Uniformity of size with thin walled cell is most desirable for crumb grain. Coarseness, thick walled cells, uneven cell size and large holes are indicative of poor grain. As shown in the Table 4. The bread containing $11 \%$ maize and $11 \%$ brown rice flour and the bread containing $14 \%$ maize and $14 \%$ brown rice flour were contained these properties. The characteristics of air cell observed for the experimental breads containing brown rice and maize flour and that of control are presented in Table 4 . The air cell size in the bread containing $11 \%$ maize and $11 \%$ brown rice flour and bread containing $14 \%$ maize and $14 \%$ brown rice flour were slightly larger than other breads.

Table 4. Effects of maize and brown rice flour on general appearances, crust and crumb characteristics of bread

\begin{tabular}{|c|c|c|c|c|c|c|c|c|c|c|c|}
\hline \multirow{3}{*}{ Bread with } & \multicolumn{3}{|c|}{ General appearance } & \multicolumn{2}{|c|}{ Crust characteristics } & \multicolumn{6}{|c|}{ Crumb characteristics } \\
\hline & \multirow[b]{2}{*}{ Evenness } & \multirow[b]{2}{*}{ Edges } & \multirow[b]{2}{*}{ Centre } & \multirow[b]{2}{*}{ Colour } & \multirow[b]{2}{*}{ Consistency } & \multirow[b]{2}{*}{ Colour } & \multirow[b]{2}{*}{ structure } & \multirow[b]{2}{*}{ Texture } & \multirow[b]{2}{*}{ Odour } & \multicolumn{2}{|c|}{ Grain } \\
\hline & & & & & & & & & & $\begin{array}{l}\text { Presence of } \\
\text { large air cell }\end{array}$ & $\begin{array}{c}\text { Shape and } \\
\text { size }\end{array}$ \\
\hline $\begin{array}{l}\text { Maize flour }=0 \\
\text { Brown rice flour =0 }\end{array}$ & Even & Medium & Medium & $\begin{array}{l}\text { Light } \\
\text { brown }\end{array}$ & Tender & $\begin{array}{l}\text { White- } \\
\text { yellow }\end{array}$ & Fine even & $\begin{array}{l}\text { soft } \\
\text { silky }\end{array}$ & Appetizing & $\begin{array}{c}\text { None or very } \\
\text { few }\end{array}$ & $\begin{array}{c}\text { Uniform, } \\
\text { thin } \\
\text { walled cells }\end{array}$ \\
\hline $\begin{array}{l}\text { Maize flour=5 } \\
\text { Brown rice flour }=5\end{array}$ & Even & Medium & Medium & brown & Tender & $\begin{array}{l}\text { White- } \\
\text { yellow }\end{array}$ & even & $\begin{array}{l}\text { Light } \\
\text { Silky }\end{array}$ & Sweet & Very few & Uniform \\
\hline \begin{tabular}{|l|} 
Maize flour $=8$ \\
Brown rice flour =8
\end{tabular} & Even & Medium & Medium & $\begin{array}{l}\text { Light } \\
\text { brown }\end{array}$ & Tender & $\begin{array}{l}\text { Slightly } \\
\text { yellow }\end{array}$ & even & $\begin{array}{l}\text { light, } \\
\text { silky }\end{array}$ & Appetizing & Very few & Uniform \\
\hline $\begin{array}{l}\text { Maize flour=11 } \\
\text { Brown rice flour }=11\end{array}$ & $\begin{array}{c}\text { Medium } \\
\text { Even }\end{array}$ & Low & Low & Brownish & $\begin{array}{l}\text { Medium } \\
\text { tender }\end{array}$ & Yellowish & $\begin{array}{c}\text { Coarse } \\
\text { even }\end{array}$ & $\begin{array}{l}\text { Light } \\
\text { silky }\end{array}$ & $\begin{array}{l}\text { Medium } \\
\text { fresh }\end{array}$ & Very few & $\begin{array}{l}\text { Less } \\
\text { uniform }\end{array}$ \\
\hline \begin{tabular}{|l|} 
Maize flour=14 \\
Brown rice flour $=14$
\end{tabular} & Uneven & Too low & Low & $\begin{array}{l}\text { deep } \\
\text { brown }\end{array}$ & $\begin{array}{l}\text { Medium } \\
\text { Tough }\end{array}$ & Yellowish & $\begin{array}{c}\text { Coarse } \\
\text { even }\end{array}$ & Light silky & $\begin{array}{l}\text { Slightly } \\
\text { fresh }\end{array}$ & few & $\begin{array}{l}\text { Non - } \\
\text { uniform }\end{array}$ \\
\hline
\end{tabular}

The effect of maize and brown rice flour on the composition of bread: In the present study five different samples of bread were processed and chemical properties were measured to assess the quality. The bread samples were analyzed for moisture, protein, fat, ash, crude fiber and total carbohydrates content. The moisture contents of five different bread samples processed with different levels of maize and brown rice flour were shown in Table 5 and showed that the moisture content of the bread without maize and brown rice flour (35.16\%) was lower than those of the other bread. The highest moisture content $40.1 \%$ was found in the bread containing $14 \%$ maize and $14 \%$ brown rice flour. It can be seen 
that the moisture content of the bread gradually increases with increasing levels of maize and brown rice flour. This might be due to the high concentration of fibers significantly increasing in water holding capacity of the higher portion of maize and brown rice flour bread. In present study it was observed that the protein contents of all samples were $7.89-6.79 \%$ much lower than that of the bread without maize and brown rice flour $8.50 \%$. It was observed that protein content in bread decreases with increasing levels of brown rice and maize flour. The might be due to the higher percentage of protein content in wheat flour (12\% protein reported by Kent, 1990). Fat content was highest $(4.29 \%)$ in sample $\mathrm{S}_{5}$ where wheat flour was substituted by $14 \%$ maize and $11 \%$ brown rice flour and lowest $(1.60 \%)$ in controlled sample. The fat contents of the bread samples increased with increasing the percentage of maize flour in dough. Since maize flour contains approximately $3.50 \%$ fat where as brown rice and wheat flour contain $2.65 \%, 0.91 \%$ fat respectively. Where as McCall et. al. (1951) found that brown rice contained 1.4-2.6\% fat and Gopalan et al., 1981 found that maize flour and wheat flour contained 3.6 and $1.6 \%$ of fat respectively.

The maximum ash was found in bread containing $14 \%$ maize and $14 \%$ brown rice flour $2.42 \%$ and lowest in the bread without maize and brown rice flour $0.85 \%$. Increasing the amount of brown rice and maize flour in breads gave increased ash content of samples. This might be due to the dry matter content of the maize and brown rice flour. In Table 5. it was shown that the highest fibre content $5.86 \%$ was obtained in the bread containing $14 \%$ maize and $14 \%$ brown rice flour and the lowest fibre content was obtained in the bread without maize and brown rice flour $0.65 \%$. This is due to the addition of increasing amount of brown rice and maize flour. The total sugar content of bread was also evaluated. The higher value $2.46 \%$ of sugar was observed in brown rice and maize flour containing bread and lower value $1.85 \%$ in bread without maize and brown rice flour.

Table 5. Composition of bread containing different levels of maize and brown rice flour ${ }^{\mathrm{a}}$

\begin{tabular}{|c|c|c|c|c|c|}
\hline \multirow[b]{2}{*}{ Components } & \multicolumn{5}{|c|}{ Bread with } \\
\hline & $\begin{array}{l}0 \% \text { maize and } \\
\text { brown rice flour }\end{array}$ & $\begin{array}{l}5 \% \text { maize and } \\
\text { brown rice flour }\end{array}$ & $\begin{array}{l}8 \% \text { maize and } \\
\text { brown rice flour }\end{array}$ & $\begin{array}{l}11 \% \text { maize and } \\
\text { brown rice flour }\end{array}$ & $\begin{array}{l}14 \% \text { maize and } \\
\text { brown rice flour }\end{array}$ \\
\hline Moisture (\%) & $\begin{array}{c}35.16 \\
(54.22 \mathrm{db})\end{array}$ & $\begin{array}{c}36.25 \\
(56.86 \mathrm{db}) \\
\end{array}$ & $\begin{array}{c}37.13 \\
(59.08 \mathrm{db}) \\
\end{array}$ & $\begin{array}{c}39.75 \\
(65.97 \mathrm{db}) \\
\end{array}$ & $\begin{array}{c}40.10 \\
(66.94 \mathrm{db}) \\
\end{array}$ \\
\hline Protein $^{b}$ & $\begin{array}{c}8.50 \\
(13.11 \mathrm{db})\end{array}$ & $\begin{array}{c}7.89 \\
(12.37 \mathrm{db})\end{array}$ & $\begin{array}{c}7.55 \\
(12.00 \mathrm{db})\end{array}$ & $\begin{array}{c}6.92 \\
(11.48 \mathrm{db})\end{array}$ & $\begin{array}{c}6.79 \\
(11.33 \mathrm{db})\end{array}$ \\
\hline Fat (\%) & $\begin{array}{c}1.60 \\
(2.46 \mathrm{db})\end{array}$ & $\begin{array}{c}3.96 \\
(6.12 \mathrm{db})\end{array}$ & $\begin{array}{c}4.10 \\
(6.52 \mathrm{db})\end{array}$ & $\begin{array}{c}4.21 \\
(6.987 \mathrm{db})\end{array}$ & $\begin{array}{c}4.29 \\
(7.16 \mathrm{db})\end{array}$ \\
\hline Ash (\%) & $\begin{array}{c}0.85 \\
(1.312 \mathrm{db})\end{array}$ & $\begin{array}{c}1.96 \\
(3.074 \mathrm{db})\end{array}$ & $\begin{array}{c}2.10 \\
(3.34 \mathrm{db})\end{array}$ & $\begin{array}{c}2.26 \\
(3.75 \mathrm{db})\end{array}$ & $\begin{array}{c}2.42 \\
(4.04 \mathrm{db})\end{array}$ \\
\hline Crude fibre & $\begin{array}{c}0.65 \\
(1.002 \mathrm{db})\end{array}$ & $\begin{array}{c}4.96 \\
(7.78 \mathrm{db})\end{array}$ & $\begin{array}{c}5.16 \\
(8.21 \mathrm{db})\end{array}$ & $\begin{array}{c}5.42 \\
(8.99 \mathrm{db})\end{array}$ & $\begin{array}{c}5.86 \\
(9.78 \mathrm{db})\end{array}$ \\
\hline Total sugar & $\begin{array}{c}1.85 \\
(2.85 \mathrm{db})\end{array}$ & $\begin{array}{c}2.13 \\
(3.34 \mathrm{db})\end{array}$ & $\begin{array}{c}2.26 \\
(3.59 \mathrm{db})\end{array}$ & $\begin{array}{c}2.39 \\
(3.966 \mathrm{db})\end{array}$ & $\begin{array}{c}2.46 \\
(4.10 \mathrm{db})\end{array}$ \\
\hline \begin{tabular}{|l|} 
Total carbohydrate \\
(\% by difference)
\end{tabular} & $\begin{array}{c}53.89 \\
(83.122 \mathrm{db})\end{array}$ & $\begin{array}{c}48.21 \\
(75.62 \mathrm{db})\end{array}$ & $\begin{array}{c}46.91 \\
(73.16 \mathrm{db})\end{array}$ & $\begin{array}{c}43.91 \\
(72.87 \mathrm{db})\end{array}$ & $\begin{array}{c}43.07 \\
(71.90 \mathrm{db})\end{array}$ \\
\hline
\end{tabular}

The parenthesis values $(\mathrm{db})$ indicate dry basis.

${ }^{a}$ Values are an averages of three determination.

${ }^{b} 6.25$ was used as a conversion factor from nitrogen to protein.

Effect of various levels of sugar, on the quality of bread containing different level of maize and brown rice flour: The optimum level of sucrose enhanced the flavor of bread but more sugar contents decreased the acceptability of bread. Different levels of maize and brown rice flour were incorporated into standard wheat flour in the bread formulation and sugar was added at the rate of $1 \%$ to $6 \%$ on the flour weight basis. Volume, specific volume, weight and moisture content were evaluated for different type of breads from Table 6 . It was observed that increasing level of sugar addition increases the bread volume, weight, moisture content. 
Table 6. Effects of various levels of sugar addition on the quality of bread containing maize and brown rice flour

\begin{tabular}{|c|c|c|c|c|c|c|c|c|c|c|c|c|c|c|c|c|}
\hline \multirow{3}{*}{$\begin{array}{l}\text { Level of } \\
\text { sugar } \\
\text { addition }\end{array}$} & \multicolumn{16}{|c|}{ Type of breads } \\
\hline & \multicolumn{4}{|c|}{$\begin{array}{c}\text { Bread with 5\% maize and 5\% } \\
\text { brown rice flour }\end{array}$} & \multicolumn{4}{|c|}{$\begin{array}{l}\text { Bread with } 8 \% \text { maize and } 8 \% \\
\text { brown rice flour }\end{array}$} & \multicolumn{4}{|c|}{$\begin{array}{c}\text { Bread with } 11 \% \text { maize and } 11 \% \\
\text { brown rice flour }\end{array}$} & \multicolumn{4}{|c|}{$\begin{array}{c}\text { Bread with } 14 \% \text { maize and } 14 \% \\
\text { brown rice flour }\end{array}$} \\
\hline & $\begin{array}{l}\text { Volume } \\
\text { (CC) }\end{array}$ & $\begin{array}{l}\text { Weight } \\
\text { (gm) }\end{array}$ & $\begin{array}{l}\text { Specific } \\
\text { volume } \\
\text { CClgm }\end{array}$ & $\begin{array}{l}\text { Moisture } \\
\text { content }\end{array}$ & $\begin{array}{l}\text { Volume } \\
\text { (CC) }\end{array}$ & $\begin{array}{l}\text { Weight } \\
\text { (gm) }\end{array}$ & $\begin{array}{l}\text { Specific } \\
\text { volume } \\
\text { CClgm }\end{array}$ & $\begin{array}{c}\text { Moisture } \\
\text { content }\end{array}$ & $\begin{array}{l}\text { Volume } \\
\text { (CC) }\end{array}$ & $\begin{array}{c}\text { Weight } \\
\text { (gm) }\end{array}$ & $\begin{array}{l}\text { Specific } \\
\text { Volume } \\
\text { CClgm }\end{array}$ & $\begin{array}{l}\text { Moisture } \\
\text { content }\end{array}$ & $\begin{array}{l}\text { Volume } \\
\text { (CC) }\end{array}$ & $\begin{array}{l}\text { Wt. } \\
\text { (gm) }\end{array}$ & $\begin{array}{l}\text { specific } \\
\text { volume } \\
\text { CClgm }\end{array}$ & $\begin{array}{r}\text { Moisture } \\
\text { Content }\end{array}$ \\
\hline 1 & & 227.5 & 2.163 & .50 & & & 2.098 & 19 & 48 & 23 & 2.085 & 36 & 485.5 & 237 & 2.049 & 35.15 \\
\hline 2 & 493 & 228 & 62 & .16 & 490 & 233.5 & 2.098 & 36.90 & 489 & 234 & 2.080 & 37.5 & 486 & 238 & .042 & 36.5 \\
\hline 3 & 33 & 228.5 & 156 & 36.93 & 491 & 234 & 2.098 & 36.99 & 489 & 235.5 & 2.076 & 37.76 & 487 & 238.5 & 2.042 & 37.79 \\
\hline 4 & T & 229 & 157 & 36.97 & 491 & 235 & 2.089 & 37.14 & 490 & \begin{tabular}{|l|l}
236.5 \\
\end{tabular} & 2.071 & 37.92 & 487.5 & 239 & 2.040 & 38.87 \\
\hline 5 & $4 y_{5}$ & 230.5 & 148 & & 92 & 23 & 2.094 & 38.04 & 491.5 & 237 & 2.073 & 38.2 & 488 & 240 & 33 & 39.1 \\
\hline 6 & 496 & 231 & 2.147 & 38.00 & 493 & 236 & 2.089 & 38.12 & 491 & 237.5 & 2.067 & 38.44 & 489 & 241 & 2.029 & 39.2 \\
\hline
\end{tabular}

Effects of various levels of yeast on the quality of bread containing maize and brown rice flour: Yeast was added in the bread formulation at the rate of $0.25 \%$ to $3 \%$ on the flour weight basis. Volume, weight and moisture content were evaluated for different type of breads and the results are given in Table 7. It was observed that the bread volume increases gradually with increasing level of yeast addition from 0.25 to $3.00 \%$. It is found that the highest volume of the bread was found at highest level of yeast addition (i.e. 3.0\%). The most acceptable level of yeast were found to be $2.5 \%$, in $8 \%$ maize and $8 \%$ brown rice flour containing bread and $2.0 \%$ in other breads. These levels of yeast addition give smooth, uniform and soft texture with the most acceptable volume of bread.

Table 7. The effects of various levels of yeast addition on the quality of bread containing maize and brown rice flour

\begin{tabular}{|c|c|c|c|c|c|c|c|c|c|c|c|c|c|c|c|c|}
\hline \multirow{3}{*}{$\begin{array}{l}\text { Level of } \\
\text { yeast } \\
\text { addition }\end{array}$} & \multicolumn{16}{|c|}{ Type of breads } \\
\hline & \multicolumn{4}{|c|}{$\begin{array}{l}\text { Bread with 5\% maize and 5\% } \\
\text { brown rice flour }\end{array}$} & \multicolumn{4}{|c|}{$\begin{array}{l}\text { Bread with } 8 \% \text { maize and } 8 \% \\
\text { brown rice flour }\end{array}$} & \multicolumn{4}{|c|}{$\begin{array}{c}\text { Bread with } 11 \% \text { maize and } 11 \% \\
\text { brown rice flour }\end{array}$} & \multicolumn{4}{|c|}{$\begin{array}{c}\text { Bread with } 14 \% \text { maize and } 14 \% \\
\text { brown rice flour }\end{array}$} \\
\hline & $\begin{array}{l}\text { Volume } \\
\text { (CC) }\end{array}$ & $\begin{array}{c}\text { Weight } \\
\text { (gm) }\end{array}$ & $\begin{array}{l}\text { Specific } \\
\text { volume } \\
\mathrm{CC} / \mathrm{gm}\end{array}$ & $\begin{array}{c}\text { Moisture } \\
\text { content }\end{array}$ & $\begin{array}{c}\text { Volume } \\
\text { (CC) }\end{array}$ & $\begin{array}{c}\text { Weight } \\
\text { (gm) }\end{array}$ & \begin{tabular}{|l} 
Specific \\
volume \\
CC/gm
\end{tabular} & $\begin{array}{c}\text { Moisture } \\
\text { content }\end{array}$ & $\begin{array}{c}\text { Volume } \\
\text { (CC) }\end{array}$ & $\begin{array}{c}\text { Weight } \\
\text { (gm) }\end{array}$ & $\begin{array}{l}\text { Specific } \\
\text { Volume } \\
\text { CC/gm }\end{array}$ & $\begin{array}{c}\text { Moisture } \\
\text { content }\end{array}$ & \begin{tabular}{|c} 
Volume \\
(CC)
\end{tabular} & $\begin{array}{c}\text { Wt. } \\
\text { (gm) }\end{array}$ & $\begin{array}{l}\text { specific } \\
\text { volume } \\
\text { CC/gm }\end{array}$ & \\
\hline 0.25 & & 227 & 2.136 & 5 & 0 & 231 & 2.078 & 34 & 484 & 230 & 2.104 & 34. & 476 & 232 & 2.051 & 35.8 \\
\hline & & $2<1.5$ & & & & 2 & & & & 231 & & & & 234.5 & & 36.0 \\
\hline 1.00 & & & & & & 233.5 & & 37.14 & 18 & 233 & & & 483 & 236 & 47 & 37.27 \\
\hline 15 & 493 & 229 & 53 & 36.7 & 489 & 235 & 880 & 37.9 & 491 & 234.5 & 094 & 37.98 & 485 & 238.5 & .034 & 38.42 \\
\hline 2.0 & 495 & 230 & 52 & 36.97 & 492 & 237 & 2.080 & 38.14 & 492 & 235 & 2.094 & 37.14 & 487 & 239 & 2.034 & 38.90 \\
\hline 2.5 & 496 & 231 & 2.147 & 37.08 & 493 & 238 & 2.071 & 38.25 & 492 & 235.5 & 2.089 & 37.9 & 488 & 240 & 2.033 & 39.05 \\
\hline
\end{tabular}

The effects of various levels of improver on the quality of maize and brown rice flour containing bread: Improver was added in the bread formulation at the rate of $0.2 \%$ to $0.7 \%$ on the flour weight basis. Volume weight, specific volume and moisture content were evaluated for different type of maize and brown rice flour containing bread and the results are given in Table 8. It was observed that the bread volume increases gradually with increasing level of improver addition from 0.2 to $0.7 \%$. In case of $8 \%$ maize and $8 \%$ brown rice flour containing bread the optimum level of improver was found to be $0.6 \%$ in order to achieve acceptable volume, texture and structure of bread.

Table 8. The effects of various levels of improver addition on the quality of bread containing maize and brown rice flour

\begin{tabular}{|c|c|c|c|c|c|c|c|c|c|c|c|c|c|c|c|c|}
\hline \multirow{3}{*}{$\begin{array}{l}\text { Level of } \\
\text { improver } \\
\text { addition }\end{array}$} & \multicolumn{16}{|c|}{ Type of breads } \\
\hline & \multicolumn{4}{|c|}{$\begin{array}{c}\text { Bread with } 5 \% \text { maize and } 5 \% \\
\text { brown rice flour }\end{array}$} & \multicolumn{4}{|c|}{$\begin{array}{c}\text { Bread with } 8 \% \text { maize and } 8 \% \\
\text { brown rice flour }\end{array}$} & \multicolumn{4}{|c|}{$\begin{array}{c}\text { Bread with } 11 \% \text { maize and } 11 \% \\
\text { brown rice flour }\end{array}$} & \multicolumn{4}{|c|}{$\begin{array}{c}\text { Bread with } 14 \% \text { maize and } 14 \% \\
\text { brown rice flour }\end{array}$} \\
\hline & $\begin{array}{c}\text { Volume } \\
\text { (CC) }\end{array}$ & $\begin{array}{c}\text { Weight } \\
\text { (gm) }\end{array}$ & $\begin{array}{c}\text { Specific } \\
\text { Volume } \\
\text { CClgm }\end{array}$ & $\begin{array}{c}\text { Moisture } \\
\text { content }\end{array}$ & $\begin{array}{c}\text { Volume } \\
\text { (CC) }\end{array}$ & $\begin{array}{c}\text { Weight } \\
\text { (gm) }\end{array}$ & $\begin{array}{l}\text { Specific } \\
\text { volume } \\
\mathrm{CClgm}\end{array}$ & $\begin{array}{c}\text { Moisture } \\
\text { content }\end{array}$ & $\begin{array}{l}\text { Volume } \\
\text { (CC) }\end{array}$ & $\begin{array}{l}\text { Weight } \\
\text { (gm) }\end{array}$ & $\begin{array}{c}\text { Specific } \\
\text { Volume } \\
\mathrm{CClgm}\end{array}$ & $\begin{array}{c}\text { Moisture } \\
\text { content }\end{array}$ & $\begin{array}{l}\text { Volume } \\
\text { (CC) }\end{array}$ & $\begin{array}{l}\text { Wt. } \\
\text { (gm) }\end{array}$ & $\begin{array}{l}\text { specific } \\
\text { volume } \\
\mathrm{CC} / \mathrm{gm}\end{array}$ & $\begin{array}{r}\text { Moisture } \\
\text { content }\end{array}$ \\
\hline 0.2 & 494 & 228.5 & 2.162 & 36.53 & 485 & 238.9 & 2.030 & 38.5 & 491 & 233 & 2.107 & 37.06 & 484 & 238 & 2.033 & 37.07 \\
\hline 0.3 & 495 & 229 & 2.162 & 36.91 & 485 & 239 & 2.029 & 38.70 & 492 & 233.5 & 2.107 & 37.21 & 485 & 239 & 2.029 & 37.52 \\
\hline 0.4 & 496 & 229 & 2.166 & 37.09 & 486 & 239.5 & 2.029 & 38.87 & 494 & 234 & 2.111 & 37.59 & 486.5 & 239.5 & 2.031 & 37.7 \\
\hline 0.5 & 498 & 230 & 2.165 & 37.14 & 487 & 239.5 & 2.033 & 39.0 & 495 & 235 & 2.106 & 37.88 & 487 & 240 & 2.029 & 38.4 \\
\hline 0.6 & 499 & 231 & 2.160 & 37.90 & 488 & 240 & 2.033 & 39.1 & 495 & 236 & 2.106 & 38.12 & 488.5 & 240.5 & 2.031 & 38.56 \\
\hline 0.7 & 500 & 232 & 2.155 & 38.01 & 489 & 241 & 2.023 & 39.2 & 496 & 236.5 & 2.097 & 38.20 & 489 & 241 & 2.029 & 38.70 \\
\hline
\end{tabular}


Effects of various level of fat on the quality of bread: The breads were prepared by adding 1 to $6 \%$ fats on the flour weight basis. The volume, weight, specific volume and moisture content of the prepared bread were evaluated and results are given in Table 9. It was observed that the bread volume increases gradually with increasing level of improver addition from 1 to $6 \%$. With the addition of 1 to $2 \%$ level of fat on the flour weight basis, the volume of bread increases slowly and the addition of 3 to $5 \%$ level of fat on the flour weight basis, the volume of bread increases sharply. The highest weight of the bread containing maize and brown rice flour was found at $6 \%$ level of fat addition and the lowest weight was obtained at the lowest level of fat addition (i.e. 1\%). This might be due to the highest water content of the bread. At various level of fat the specific volume of bread were approximately same for each sample. The moisture content of bread ranges from 34 to $39.50 \%$ with the addition of different level of fat on the flour weight basis.

Table 9. The effects of various levels of fat addition on the quality of bread containing maize and brown rice flour

\begin{tabular}{|c|c|c|c|c|c|c|c|c|c|c|c|c|c|c|c|c|}
\hline \multirow{3}{*}{$\begin{array}{l}\text { Level of } \\
\text { fat } \\
\text { addition }\end{array}$} & \multicolumn{16}{|c|}{ Type of breads } \\
\hline & \multicolumn{4}{|c|}{$\begin{array}{c}\text { Bread with } 5 \% \text { maize and } 5 \% \\
\text { brown rice flour }\end{array}$} & \multicolumn{4}{|c|}{$\begin{array}{c}\text { Bread with } 8 \% \text { maize and } 8 \% \\
\text { brown rice flour }\end{array}$} & \multicolumn{4}{|c|}{$\begin{array}{c}\text { Bread with } 11 \% \text { maize and } 11 \% \\
\text { brown rice flour }\end{array}$} & \multicolumn{4}{|c|}{$\begin{array}{c}\text { Bread with } 14 \% \text { maize and } 14 \% \\
\text { brown rice flour }\end{array}$} \\
\hline & $\begin{array}{c}\text { Volume } \\
\text { (CC) }\end{array} \mid$ & $\begin{array}{c}\text { Weight } \\
\text { (gm) }\end{array}$ & \begin{tabular}{|l|} 
Specific \\
Volume \\
CClgm \\
\end{tabular} & $\begin{array}{c}\text { Moisture } \\
\text { content }\end{array}$ & $\begin{array}{c}\text { Volume } \\
\text { (CC) }\end{array}$ & $\begin{array}{c}\text { Weight } \\
\text { (gm) }\end{array}$ & $\begin{array}{l}\text { Specific } \\
\text { volume } \\
\text { CC/gm }\end{array}$ & $\begin{array}{c}\text { Moisture } \\
\text { Content }\end{array}$ & $\begin{array}{l}\text { Volume } \\
\text { (CC) }\end{array}$ & $\begin{array}{l}\text { Weight } \\
\text { (gm) }\end{array}$ & \begin{tabular}{|l|} 
Specific \\
Volume \\
CClgm \\
\end{tabular} & $\begin{array}{c}\text { Moisture } \\
\text { content }\end{array}$ & $\begin{array}{l}\text { Volume } \\
\text { (CC) }\end{array}$ & $\begin{array}{l}\text { Wt. } \\
\text { (gm) }\end{array}$ & $\begin{array}{l}\text { specific } \\
\text { volume } \\
\text { CC/gm }\end{array}$ & $\begin{array}{l}\text { Moisture } \\
\text { content }\end{array}$ \\
\hline 1 & 492 & 228 & \begin{tabular}{|l|}
2.158 \\
\end{tabular} & 34.00 & 489 & 234.5 & 2.072 & 35.00 & 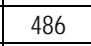 & 232 & 2.108 & 35.19 & 485 & 238.5 & 2.036 & 36.9 \\
\hline 2 & 493 & 229 & 2.153 & 34.14 & 489 & 235 & 2.070 & 36.77 & 486.5 & 233 & 2.098 & 35.52 & 485 & 239 & 2.030 & 37.47 \\
\hline 3 & 493 & 229.5 & 2.148 & 35.32 & 490 & 236 & 2.063 & 37.01 & 487 & 233.5 & 2.098 & 36.34 & 486 & 239 & 2.033 & 38.11 \\
\hline 4 & 495 & 230 & 2.152 & 36.90 & 491 & 237 & 2.063 & 37.57 & 489 & 234 & 2.098 & 37.20 & 487 & 239.5 & 2.033 & 38.83 \\
\hline 5 & 495 & 231 & 2.143 & 37.87 & 492 & 237.5 & 2.063 & 38.13 & 489.5 & 234.5 & 2.098 & 38.388 & 488 & 240 & 2.033 & 39.10 \\
\hline 6 & 496 & 231 & 2.147 & 37.99 & 493 & 238 & 2.058 & 38.20 & 490 & 235 & 2.098 & 38.50 & 488.5 & 241 & 2.027 & 39.50 \\
\hline
\end{tabular}

Sensory Evaluation of bread containing maize and brown rice flour: From the results of mean sensory score, it was apparent that there was significant $(P<0.05)$ difference in overall acceptability among the breads. The results (Table 10) indicate that the overall acceptability of control bread and the bread containing $8 \%$ maize and $8 \%$ brown rice flour were equally acceptable. The DMRT test for overall acceptability preference was performed and the results are given in Table 10. The bread without maize and brown rice flour scored the highest score for overall acceptability among the other bread containing maize and brown rice flour. The overall acceptability of bread containing $11 \%$ maize and $11 \%$ brown rice flour and the bread containing $14 \%$ maize and $14 \%$ brown rice flour were equally acceptable. These bread were significantly different from the bread without maize and brown rice flour, bread containing $8 \%$ maize and $8 \%$ brown rice flour and the bread containing 5\% maize and 5\% brown rice flour. It was also observed that the bread containing $8 \%$ maize and $8 \%$ brown rice flour secured the highest scored overall acceptability among the samples with maize and brown rice flour while bread containing $14 \%$ maize and $14 \%$ brown rice flour obtained the lowest among breads.

Table 10. Mean sensory scores of breads for control and the breads containing maize and brown rice flour

\begin{tabular}{|l|c|c|c|c|}
\hline \multirow{2}{*}{ Bread with } & \multicolumn{4}{|c|}{ Sensory attributes } \\
\cline { 2 - 5 } & Colour & Flavour & Texture & Overall acceptability \\
\hline $0 \%$ maize and brown rice flour & $8.813^{\mathrm{a}}$ & $8.688^{\mathrm{a}}$ & $8.250^{\mathrm{a}}$ & $8.813^{\mathrm{a}}$ \\
\hline $5 \%$ maize and brown rice flour & $7.938^{\mathrm{b}}$ & $7.563^{\mathrm{b}}$ & $7.188^{\mathrm{b}}$ & $7.875^{\mathrm{b}}$ \\
\hline $8 \%$ maize and brown rice flour & $8.563^{\mathrm{a}}$ & $7.940^{\mathrm{b}}$ & $7.687^{\mathrm{b}}$ & $8.500^{\mathrm{a}}$ \\
\hline $11 \%$ maize and brown rice flour & $7.188^{\mathrm{c}}$ & $6.438^{\mathrm{c}}$ & $6.375^{\mathrm{c}}$ & $6.750^{\mathrm{c}}$ \\
\hline $14 \%$ maize and brown rice flour & $7.063^{\mathrm{c}}$ & $5.875^{\mathrm{d}}$ & $6.188^{\mathrm{c}}$ & $6.438^{\mathrm{c}}$ \\
\hline LSD (P<0.05) & 0.2873 & 0.3171 & 0.5386 & 0.3317 \\
\hline
\end{tabular}

Mean with same superscript within a column are not significantly different at $p<0.05$ 


\section{References}

AOAC. 2004. Official method of Analysis of the Association of official Analytical chemists. 15th Ed. Washington. DC.

Gopalan, C., Rama Sastri, B.V. and Balasubramanian, S.C. 1981. Nutritive value of Indian foods. National institute of nutrition. ICMR, Hyderabad, India

Grist, D.H. 1965. Rice 4th Ed. Longamans, London. 66.

Juliano, B.O. 1972. The rice caryopsis and Lts composition; In; Houston, D.F. (Ed), Rice Chemistry and Technology. Am. Assoc. Cereal chemistry, Inc. St. Paul. Minn. 16.

Kent, N.L. 1984. Technology of cereal: An introduction for students of food science and agriculture, 3rd edition, Pergamon Press, Oxford.

Kent, N.L. 1990. Technology of cereals: An Introduction of Students of Food Science and Agriculture. Third edition. Pergamon Press, Oxford.

Lynn, J. 1969. Edible rice bran Foods. In protein enriched cereal Foods for world needs. M. Milner (Editor). Amer. Assoc, Cereal Chem., St. Paul, Minn.

Martin, J.H. and Leonard, W.H.. 1967. Principle of Field Crop Production. The McMillan and Co., New York.

Mccall, Elizabeth, R., Hoff., Pauir, Carrol, L. and Skau; Dororthy, B. 1951. The chemical composition of rice. A literature review. U.S. Dept. Bur. Agr. Ind. Chem. Mimco Cire. AIC-312,49.

Ott, D.B. 1987. Applied Food Science Manual. Michigan State University. Pergramon press, USA.

Pomeranz, Y. and Shellenerger. 1971. Bread science and Technology, 2nd Ed. Westport, Connecticut.

Sayre, R.N., Saunders, R.M., Enochian, R.V., Schultz, W.G. and Beagle, E.C. 1982. Review of rice bran stabilization systems with emphasis on extrusion cooking. Cereal foods world 27:317-322. 